FACTA UNIVERSITATIS

Series: Physical Education and Sport, Vol. 18, No 3, 2020, pp. 681 - 692

https://doi.org/10.22190/FUPES201106064P

Research article

\title{
PHYSICAL EDUCATION: PRACTICE, CESSATION AND RESUMPTION IN UNTRAINED SAUDI COLLEGE STUDENTS
}

UDC 796.371.212(532)

\author{
Pablo Prieto-González ${ }^{1}$, Jaromir Sedlacek ${ }^{2}$ \\ ${ }^{1}$ Department of Physical Education, Health, and Recreation, \\ Prince Sultan University, Riyadh, Saudi Arabia \\ ${ }^{2}$ Faculty of Sport, Presov University, Presov, Slovakia
}

\begin{abstract}
The aim of the present study was twofold: firstly, to verify whether two classes a week of Physical Education (PE) are sufficient to improve physical fitness in college students. Secondly, to ascertain the effect of PE practice, cessation and resumption on the mentioned students. Thirty (30) untrained Saudi college students attended PE lessons twice a week for nine weeks. Subsequently, they were inactive for nine weeks, and finally, they attended PE classes again another period of nine weeks. After the two nine-week periods of PE, the participants improved their strength, endurance, speed and agility. The period of inactivity implied the loss of all the adaptations attained during the first nine weeks of practice, except muscular endurance in the trunk flexor muscles. Two classes a week of PE during nine weeks improve physical fitness in untrained university students. These improvements almost entirely decay after nine weeks of inactivity, but can be recovered with another nine weeks of $P E$ classes. Individuals who resume PE lessons after nine weeks of PE followed by a nine-week inactivity period, could attain higher improvements in specific physical capacities (muscular endurance, cardiovascular endurance, speed and agility).
\end{abstract}

Key words: Physical Education, Continuity, Frequency, Reversibility

\section{INTRODUCTION}

Current scientific evidence indicates that university students neither practice enough physical exercise, nor comply with the global recommendations on Physical Activity (PA) established by the World Health Organization. This phenomenon is not limited to specific countries, but affects college students from all continents (Irwin et al., 2004;

Received November 06, 2020 / Accepted December 12, 2020

Corresponding author: Pablo Prieto-González

Department of Physical Education, Health, and Recreation, Prince Sultan University, Box 66833, Riyadh 11586, Riyadh, Saudi Arabia

Phone: +966 114948000•E-mail: pabloccjb@gmail.com

(C) 2020 by University of Niš, Serbia | Creative Commons License: CC BY-NC-ND 
Clemente, Nikolaidis, Martins, \& Mendes, 2016; Griban et al., 2020; Lipert et al., 2020; Mandić et al., 2020). In Saudi Arabia, recent studies addressing this aspect have reported low levels of PA practice (El Bcheraoui et al., 2016; Almutairi et al., 2018).

Besides, some research indicates that as students complete each academic year, this trend becomes accentuated. Junior students practice less PA than sophomore students, which in turn, less than freshmen students (Meckel, Galily, Nemet, \& Eliakim, 2011).

To reverse this situation, Physical Education (PE) teachers have the responsibility to foster lifetime habits of PA practice among the students, promoting a constructive and healthy use of leisure time (Fausto-Iván \& Aldas-Arcos, 2019; Hall-López, 2020). Their daily work is essential in improving public health and people's quality of life since $\mathrm{PE}$ has a positive impact on students at physical, psychological and social levels (Harris, 2015; Wang, 2019).

The practice of PA also reduces the appearance of risk factors associated with chronic diseases. Therefore, PE teachers should try to improve the motor competence and motivation towards exercise of their students, enabling them to dominate a wide variety of sporting disciplines to ensure PA adherence (Harris, 2015).

However, to benefit from the health effects derived from participating in PA programs, the practice should be frequent and continuous (Zamarripa-Rivera, Ruiz-Juan, LópezWalle, \& Fernández, 2014). Otherwise, there would be a progressive loss of the adaptations attained through exercise, following the principle of reversibility (Tsolakis, Vagenas, \& Dessypris, 2004).

As for the weekly frequency of practice, recent research has analyzed the PE Curriculum time allocation on Primary and Secondary Education (Kühr, Lima, Grøntved, Wedderkopp, \& Klakk, 2020). However, very few studies have addressed this aspect in college students. Even so, it has been verified that, at the university level, the higher academic workload and long hours of study impede the PA practice as often as needed (Calestine, Bopp, Bopp, \& Papalia, 2017).

Regarding the continued practice of PA, in countries such as Saudi Arabia, it has been found that participants significantly decrease the frequency of regular practice of PA once they enter University. Undoubtedly, the higher academic demand makes it difficult for college students to exercise regularly throughout the year (Alkhateeb et al., 2019).

This circumstance is aggravated at certain times, such as final exam periods, and could, in some cases, lead to a temporary cessation of practice. If so, we would be talking about PA practice, cessation and resumption. This phenomenon, known in the field of sport as training, detraining and retraining, has been studied in different age groups (Psilander et al., 2019; Blocquiaux et al., 2020). However, no previous study has examined the effect of PE practice, cessation and resumption in college-age students.

In this context, the aim of the present study was twofold: firstly, to verify whether two weekly sessions of PE are sufficient to improve physical fitness in Saudi college students. Secondly, to ascertain the effect of PE practice, cessation and resumption on the mentioned students.

\section{METHODS}

\section{Participants}

Thirty (30) Saudi male college students (Age: 19.11 \pm 0.56 ; Mass: 76.31 \pm 11.42 ; Height: 175.64 \pm 6.72 ; BMI: $24.69 \pm 3.42$ ) voluntarily participated in the present study. The 
inclusion criteria were: a) Have not practiced either regular or structured physical exercise in the last five years; b) Did not suffer injuries or chronic diseases; c) Were a non-smoker; d) Had a BMI lower than 30; and e) Were not on a diet.

All of the participants were informed about the objectives, risks and benefits derived from their inclusion in the study. They also signed an informed consent form indicating their willingness to participate. The present study was carried out according to the Declaration of Helsinki ethical principles. It was also approved by the Institutional Review Board of the Bioethics Committee of Price Sultan University (Riyadh, Saudi Arabia).

\section{Procedures}

The research was carried out at Prince Sultan University within the "Physical Education I" and "Physical Education II" courses. Both are mandatory courses for all freshmen students and are respectively taught in the first and second semester twice a week.

The intervention had a total duration of 27 weeks (see Figure 1). Both in the intervention period 1 and 2, an individual sport, a racket sport and a team sport were practiced for three weeks, as set out in the Academic Curriculum. PE lessons were held on Sunday and Tuesday, from 2:00 p.m. to 2:50 p.m. or from 3:00 p.m. to 3:50 p.m. The period of inactivity between the $10^{\text {th }}$ and the $18^{\text {th }}$ week coincided with the period of final exams of the first semester (three weeks), with the holiday week between the first and second semester, and with the first five weeks of the second semester, in which only theoretical contents were taught in the Physical Education II course. During this period of inactivity, the study participants were not required to take part in physical activity. As for the tests, the pre-test 1 (PreT1) and pre-test 2 (PreT2) were carried out the week before starting the intervention period 1 and 2, while post-test 1 (PT1) and post-test 2 (PT2) were carried out respectively in the ninth and $27^{\text {th }}$ week, 48 hours after the last PE class.

\begin{tabular}{|c|c|c|c|c|c|c|c|}
\hline PreT1 & & $\mathrm{PT}$ & $\begin{array}{c}\text { PreT2 } \\
\nabla\end{array}$ & & PT2 & & \\
\hline Period & & erventic & & Inactivity & & ntervention 2 & \\
\hline Week & $1-3$ & $4-6$ & $7-9$ & $10-18$ & $19-21$ & $22-24$ & $25-27$ \\
\hline Activity & Swimming & $\begin{array}{l}\text { Table } \\
\text { Tennis }\end{array}$ & Basketball & None & Fitness & Badminton & Soccer \\
\hline
\end{tabular}

Fig. 1 Intervention timeline

The session content of intervention periods 1 and 2 is detailed in tables 1 and 2, respectively. It was designed based on the proposal of Fernández-Bustos, MéndezGiménez, \& Sánchez-Gómez (2018). The duration of each session was 50min. In the first $10 \mathrm{~min}$, a warm-up was carried out. It consisted of two phases. An initial general phase, which included muscle activation and joint mobility, and a specific phase, comprising sport-specific movements. Likewise, the last five minutes of each session were devoted to cooling down by performing jogging and stretching exercises. During the session, the following teaching methodological guidelines were followed (Ramos, 2000): a) Increasing time for instruction; b) Reducing transition time; c) Avoiding time-consuming explanations and demonstrations. d) Using feedback to improve student motivation; e) Avoiding elimination games and activities; and f) Once the students learned the basic skills of each sport, activities to apply them in real game situations were proposed. 
Table 1 Intervention period 1. Sequence of contents

\begin{tabular}{|c|c|c|c|}
\hline & Swimming & Table Tennis & Basketball \\
\hline Session 1 & $\begin{array}{l}\text { Breathing, flotation and } \\
\text { propulsion }\end{array}$ & $\begin{array}{l}\text { Familiarization exercises } \\
\text { with a racket and ball. } \\
\text { Backhand and forehand }\end{array}$ & $\begin{array}{l}\text { Drills and games to } \\
\text { practice low and speed } \\
\text { dribble without and with } \\
\text { opposition }\end{array}$ \\
\hline Session 2 & $\begin{array}{l}\text { Crawl: Analytical exercises, } \\
\text { kicking and coordination }\end{array}$ & $\begin{array}{l}\text { Backhand, forehand and } \\
\text { service }\end{array}$ & $\begin{array}{l}\text { Chest, bounce and } \\
\text { overhead pass without } \\
\text { and with opposition. } 10 \\
\text { pass game }\end{array}$ \\
\hline Session 3 & $\begin{array}{l}\text { Crawl: Arm stroke, contrast } \\
\text { exercises, and exercises to } \\
\text { reduce drag }\end{array}$ & $\begin{array}{l}\text { Short explanation (Tactics } \\
\text { and rules). Table tennis } \\
\text { match pairing the players } \\
\text { according to their skill and } \\
\text { ability level }\end{array}$ & $\begin{array}{l}\text { Lay-up. Mid-range shot. } \\
\text { Free Throw. Game of } 21\end{array}$ \\
\hline Session 4 & $\begin{array}{l}\text { Backstroke: Analytical } \\
\text { exercises, kicking and } \\
\text { coordination }\end{array}$ & Tournament (singles) & $\begin{array}{l}\text { Dribbling: Reverse, } \\
\text { between the legs, behind } \\
\text { the Back. } 3 \times 3 \text { game }\end{array}$ \\
\hline Session 5 & $\begin{array}{l}\text { Backstroke: Arm stroke, } \\
\text { contrast exercises, and exercises } \\
\text { to reduce drag }\end{array}$ & Tournament (doubles) & $\begin{array}{l}\text { Short explanation } \\
\text { (Tactics and rules). } \\
\text { Basketball game }\end{array}$ \\
\hline Session 6 & $\begin{array}{l}\text { Lifesaving introduction: } \\
\text { Lifesaving swimming. Manikin } \\
\text { carry with and without material }\end{array}$ & King of the court game & Tournament \\
\hline
\end{tabular}

Table 2 Intervention period 2. Sequence of contents

\begin{tabular}{|c|c|c|c|}
\hline & Weight training & Badminton & Soccer \\
\hline Session 1 & $\begin{array}{l}\text { Resistance training: } \\
\text { Intensity: } 58 \% \text { 1RM } \\
\text { Sets: } 3 \\
\text { Reps: } 14 \\
\text { Rest: } 1 \text { min } \\
\text { Number of exercises: } 8 \text { (lower } \\
\text { body, core and upper body) }\end{array}$ & $\begin{array}{l}\text { Familiarization with the } \\
\text { racket and shuttle. Clear- } \\
\text { drop; forehand-backhand }\end{array}$ & $\begin{array}{l}\text { Pass. Control. Rondo } \\
\text { game }\end{array}$ \\
\hline Session 2 & Idem session 1 & $\begin{array}{l}\text { Clear-lop; forehand- } \\
\text { backhand; lob-smash. Service }\end{array}$ & $\begin{array}{l}\text { Pass. Control. Dribbling. } \\
\text { Team possession }\end{array}$ \\
\hline Session 3 & $\begin{array}{l}\text { Resistance training: } \\
\text { Intensity: } 62 \% \text { 1RM } \\
\text { Sets: } 3 \\
\text { Reps: } 12 \\
\text { Rest: } 90 \text { sec } \\
\text { Number of exercises: } 8 \text { (lower } \\
\text { body, core and upper body) }\end{array}$ & $\begin{array}{l}\text { Short explanation (rules: } \\
\text { singles and doubles). Practice } \\
\text { of the basic shots. Game } \\
\text { (singles) }\end{array}$ & $\begin{array}{l}\text { Shooting. Skill Circuit: } \\
\text { Passing, Dribbling and } \\
\text { Shooting }\end{array}$ \\
\hline Session 4 & Idem session 1 & Tournament (singles) & $\begin{array}{l}\text { Practice of defensive } \\
\text { transitions and attacks. } \\
\text { Soccer game with } 3 \text { goals }\end{array}$ \\
\hline Session 5 & $\begin{array}{l}\text { Strength training: } \\
\text { Intensity: } 66 \% \text { 1RM } \\
\text { Series: } 3 \\
\text { Reps: } 10 \\
\text { Rest: } 2 \text { min } \\
\text { Number of exercises: } 8 \text { (lower } \\
\text { body, core and upper body) }\end{array}$ & $\begin{array}{l}\text { Explanation (Tactics) } \\
\text { Tournament (doubles) }\end{array}$ & $\begin{array}{l}\text { Brief explanation (rules } \\
\text { and tactical aspects). } \\
\text { Soccer game } 3 \times 3\end{array}$ \\
\hline Session 6 & Idem session 1 & King of the court & Soccer tournament \\
\hline
\end{tabular}




\section{Evaluation}

The following five tests were used in the PreT1, PreT2, PT1 and PT2:

1-minute sit-up test ( $S U)$ : It was used to assess the muscular endurance of the trunk flexor muscles. It was included due to its high reliability (Waldhelm \& $\mathrm{Li}, 2012$ ). The objective of the test was to perform as many sit-ups as possible in $1 \mathrm{~min}$. The materials used were a Delta Fitness $(\subset$ mat (Jeddah, Saudi Arabia) and a Casio $\bigodot$ digital stopwatch model HS-3V-1BRDT (Mathura, New Delhi, India). To perform this test, the protocol set by the American Alliance for Health, Physical Education, Recreation and Dance (1980) was followed. The participant was in the supine position on a mat, with arms crossed over his chest, and knees bent at $90^{\circ}$. His feet were held on the ground by one partner. Only correct repetitions were registered. That is to say, the participant had to touch the mat with his scapulas when extending the trunk, and with his elbows on the knees when bending the trunk. Each participant had one attempt.

1-minute push-up test $(P U)$ : It was included due to its high validity and reliability (Hashim, Ariffin, Hashim, \& Yusof, 2018). It was used to assess the muscular endurance of the upper body muscles. The material used was the same as in the previous test. The student was in the prone position, with his hands under the shoulders, fingers pointing forward and elbows bent at $90^{\circ}$. The trunk and lower extremities were aligned. The participant had to perform as many push-ups as possible in $1 \mathrm{~min}$. Only correctly performed repetitions were registered, meaning, those repetitions in which the student fully extended his arms when raising the trunk. And later, bent his elbows at a $90^{\circ}$ angle when lowering the body. Each participant had one attempt.

Standing long jump (SLJ): It was used to assess the explosive strength of the lower body due to its high validity and reliability (Fernández-Santos, Ruiz, Cohen, GonzálezMontesinos, \& Castro-Piñero, 2015; Reid, Dolan, \& Debeliso, 2017). To carry out this test, a Gamecraft $\odot$ Carpeted Long Jump Mat (Dublin, Ireland) was used. The participant stood behind the take-off line with his feet parallel. The objective of the test was to jump as far as possible, landing with both feet simultaneously. The measurement was taken from the take-off line and the nearest back of the heel. Each participant had two attempts.

$4 \times 10 \mathrm{~m}$ shuttle run test (SHR): It was used to measure speed and agility, and was selected due to its reliability (Ramírez-Vélez, Rodrigues-Bezerra, Correa-Bautista, Izquierdo, \& Lobelo, 2015). The protocol established by the ALPHA health-related fitness test project was followed (Ruiz et al., 2011). The test was carried out on a non-slip sports court. Two parallel lines were marked on the floor at 10 meters. One sponge (B) was placed on the starting line, and two sponges (A and $\mathrm{C}$ ) on the opposite line. On the teacher's signal, the student ran to the opposite line and picked up the sponge (A). Then, he returned to the starting line and exchanged sponge (A) for sponge (B). Afterward, he returned to the opposite line and exchanged sponge (B) for sponge (C), and later, he returned to the starting line to finish the test. The objective of the test was to carry out the actions previously described as quickly as possible. Time was recorded using a Timer ( S4 Alge-Timing photocells (Lustenau, Australia). Each participant had one attempt.

$1 \mathrm{~km}$ run fitness test $(1 \mathrm{KM})$ : This test was used to assess cardiovascular endurance. It was selected due to its high validity and reliability to estimate VO2max (García-García, Ramos-Bermúdez, \& Aguirre, 2016). The participants had to complete 1KM as quickly as possible. The test was carried out on a Cybex 625T treadmill (Rosemont, Illinois, USA), in an air-conditioned fitness room, due to the high temperatures reached in Riyadh 
most of the year. Participants had only one attempt. They were themselves responsible for selecting the speed of the treadmill.

Before conducting the tests, the participants performed a 10-minute warm-up, which included two phases of five minutes each: muscle activation and joint mobility. Likewise, the participants were encouraged to perform at their best in the five tests undertaken.

\section{Statistical analysis}

Results are presented as mean (standard deviation). The normality of the data was verified by using the Shapiro-Wilk test. Intraclass correlation coefficients were calculated for dependent variables, obtaining values greater than .91 on all of them. To assess the effect of each period on dependent variables, a one-way ANOVA with repeated measures was conducted. Since multiple comparisons were made, the Bonferroni correction was applied to adjust the confidence intervals. The effect size was estimated by using the partial eta squared parameter $\left(\eta^{2}\right)$. Effect sizes of .02 were considered small, .13 medium, and .26 large (Bakeman, 2005). Statistical analysis was performed using the Statistical Package for Social Sciences (SPSS Inc, version 22.0 Chicago, IL, USA). The level of significance was set at $\mathrm{p}<.05$.

\section{RESULTS}

$S U$ : The ANOVA showed a significant period effect, with a large effect size $(\mathrm{p}<.001$; $\eta^{2}=.937$ ). As shown in table 3 and in Figure $2 a$, marks obtained on PreT1 were significantly lower than those attained on PT1 ( $\mathrm{p}=.003)$, in PreT2 ( $<<.001)$ and on PT2 ( $<<.001)$. However, no significant differences were found between the PT1 and PreT2 results $(p=0.234)$. The marks achieved on PT1 were significantly lower than those of PT2 (p<.001). Likewise, the PreT2 results were significantly worse than those of the PT2 ( $<<.001)$.

$P U$ : The ANOVA indicated a significant period effect, with a large effect size $(\mathrm{p}<.001$; $\left.\eta_{\mathrm{p}}^{2}=.753\right)$. The PreT1 results were significantly lower than those of PT1 ( $\left.<<.001\right)$, and those of PT2 ( $\mathrm{p}=.049)$. However, there were no significant differences between the PreT1 and PreT2 marks $(\mathrm{p}=.763)$. The marks obtained on PT1 were significantly better than those obtained on PreT2 $(\mathrm{p}<.001)$. Nevertheless, no significant differences were observed between the PT1 and the PT2 results ( $\mathrm{p}=.094)$. The PreT2 marks were significantly worse than those of the PT2 (p<.001) (see table 3 and figure $2 b$ ).

$S L J$ : The ANOVA revealed a significant main effect of period, and a large effect size $\left(\mathrm{p}<.001 ; \eta_{\mathrm{p}}^{2}=.787\right)$. Marks attained on PreT1 were significantly lower than those accomplished on PT1 ( $\mathrm{p}<.001)$, and in PT2 ( $\mathrm{p}=.047)$. No significant differences were observed between the PreT1 and PreT2 results $(\mathrm{p}=.986)$. Marks attained on PT1 were significantly better than those obtained on PreT2 $(\mathrm{p}=.007)$, but there were no significant differences between PT1 and PT2 results $(\mathrm{p}=.668)$. It was also observed that the marks achieved on PreT2 were significantly lower than those attained on PT2 ( $\mathrm{p}<.001)$ (see table 3 and figure $2 \mathrm{c}$ ).

SHR: The ANOVA showed a significant main period effect, with a large effect size $\left(\mathrm{p}<.001 ; \eta_{\mathrm{p}}^{2}=.981\right)$. The marks attained on PreT1 were significantly worse than those of PT1 $(\mathrm{p}<.001)$ and those of PT2 ( $<<.001)$. However, no significant differences were found between PreT1 and PreT2 results $(\mathrm{p}=.11)$. Marks achieved on PT1 were significantly better 
than those of PreT2 (p<.001) and significantly worse than those of PT2 (p<.001). The PreT2 marks were significantly lower than those of PT2 (p<.001) (see table 3 and figure $2 d$ ).

1KM: The ANOVA revealed a significant main period effect, with a large effect size $\left(\mathrm{p}<.001 ; \eta_{\mathrm{p}}^{2}=.930\right)$. Marks obtained on PreT1 were significantly lower than those attained on PT1 ( $\mathrm{p}<.001)$ and on PT2 (p<.001). No significant differences were observed between PreT1 and PreT2 results. The marks of PT1 were significantly better than those of PreT2 $(p<.001)$, and significantly lower than those of PT2. Finally, the results achieved in PT2 were significantly better than those accomplished on PreT2 $((\mathrm{p}<.001)$ (see table 3 and figure 2e).

Table 3 Results obtained on the physical condition tests

\begin{tabular}{llllll}
\hline & SU & PU & SLJ & SHR & 1KM \\
\hline Pre-test & $35.61(3.93)$ & $21.73(4.27)$ & $168.33(11.54)$ & $12.31(0.39)$ & $6.13(0.74)$ \\
Pos-test 1 & $37.01(2.99)+$ & $24.83(4.73)+$ & $171.66(10.85)+$ & $12.18(0.38)+$ & $5.48(0.67)+$ \\
Pre-test 2 & $37.83(4.32)+$ & $20.21(9.04) *$ & $166.43(19.61) *$ & $12.51(0.67) *$ & $6.12(0.92) *$ \\
PreT1est 1 & $40.46(4.37)$ & $23.61(8.93)$ & $174.09(21.59)$ & $11.63(0.65)$ & $5.29(0.92)$ \\
& $+* \#$ & $+\#$ & $+\#$ & $+* \#$ & $+* \#$ \\
\hline
\end{tabular}

Note: +: Significant difference from the PreT1;

*: Significant difference from the PT1; \#: Significant difference from the PreT2.
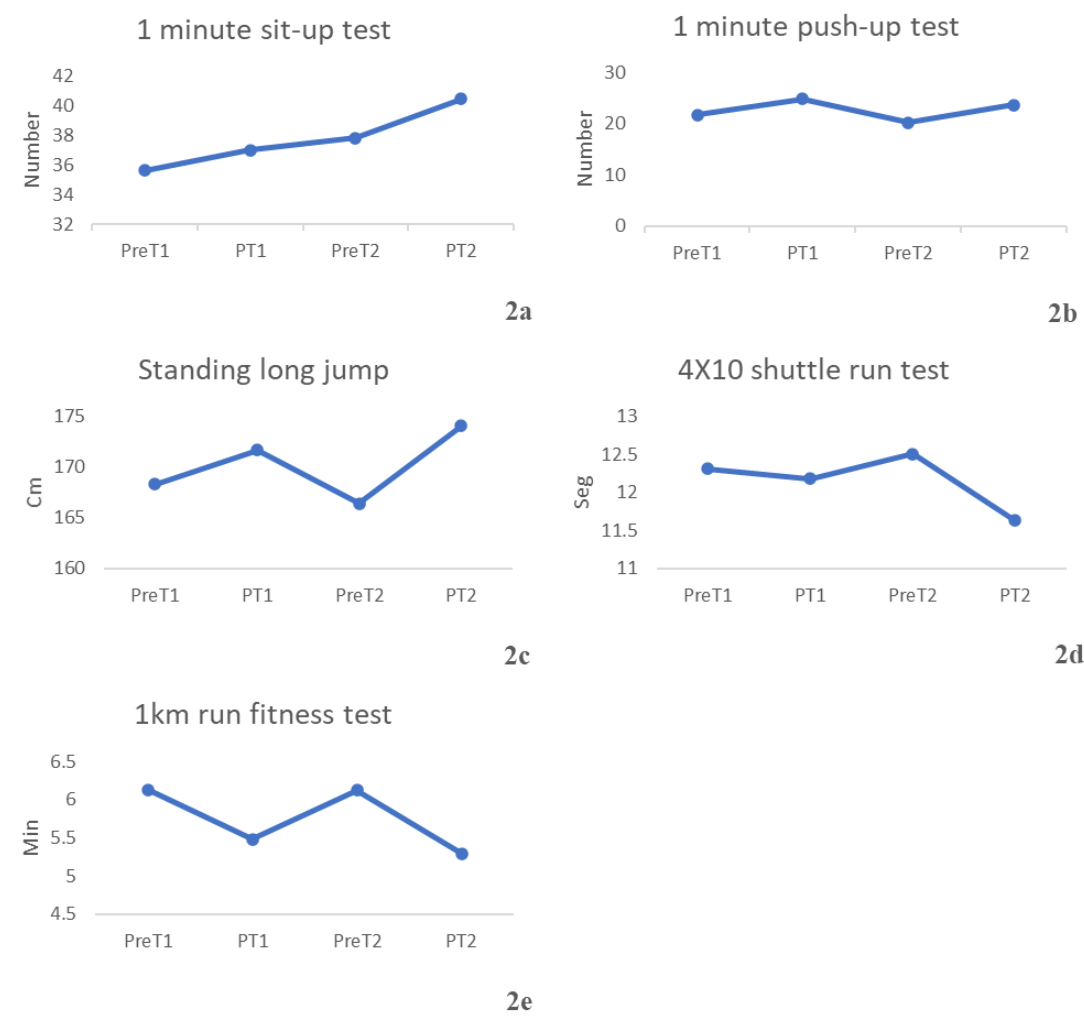

Fig. 2 Evolution of the results obtained by the participants 


\section{DISCUSSION}

The results of the present study have revealed that, in untrained college-age students, the practice of individual, racket and team sports within PE courses for nine weeks generates significant physical fitness improvements. Specifically, those adaptations were attained in trunk flexors and upper body muscular endurance, lower body explosive strength, cardiorespiratory resistance, speed and agility. These results are consistent with recent studies that have verified that sports practice positively impacts physical fitness (Oliveira, Monteiro, Jácome, Afreixo, \& Marques, 2017).

However, the inactivity period of nine weeks set after the intervention period 1 , implied the deterioration of all fitness test results, except for the SU. Therefore, as previously observed in the sports field with detraining periods, it was verified that the adaptations attained with the PE classes are also reversible when stimulation ceases (Bosquet \& Mujika, 2012). This circumstance highlights the importance of the training principle of continuity (Aceña, Díaz, González, Juárez, \& Navarro, 2007).

SLJ mark deterioration on PreT2 is consistent with the study carried out by Chtourou et al. (2015). They found out that, after three weeks of detraining, it is possible to partially maintain lower body levels of explosive strength in college-aged participants. However, after five weeks, the adaptations attained deteriorated.

Bosquet and Mujika (2012) explain that both VO2max and cardiovascular endurance experience a significant deterioration during the first three or four weeks of detraining, due to the higher lactate concentration and dropped VO2max levels. This rapid loss of adaptations could explain the 1KM marks deterioration on PreT2.

SHR results deterioration on PreT2 is also consistent with previous research. Komsis and associates (2018), in one study carried out with soccer players aged between 19 and 24 , verified that a 4-week detraining period resulted in a significant deterioration in speed and agility. Furthermore, it must be taken into account that both speed and agility depend on strength levels, particularly on explosive strength (Borges, 2014). And as mentioned previously, explosive strength significantly dropped after the 9-week inactivity period.

As for the SU and PU, despite both tests assessing muscular endurance, the participants were able to maintain their marks after nine weeks of inactivity in the SU but not in PU. Therefore, these results suggest that it is not clear whether nine weeks of inactivity involve the loss of all the adaptations achieved. In this respect, some studies showed contradictory results, which does not clarify this aspect. Tran and associates (2017) observed that a significant strength deterioration occurs in adolescents after a 4week period of detraining. In contrast, Gavanda, Geisler, Quitmann, Bauhaus, and Schiffer (2020) verified that a 3-week period of detraining did not result in decreased strength and hypertrophy. Aceña and associates (2007) found in untrained participants aged between 18 and 24 that strength levels did not decay after an 8-week detraining period. Ronconia and Alvero-Cruza (2008) indicate that, in young participants, strength loss is slower than senior citizens. Another factor which could explain the lack of consistency between the SU and PU marks on the PreT2 is that obtaining good result on PU does not depends only on muscular endurance, but also on the relative strength (Alizadeh, Rayner, Mahmoud, \& Behm, 2020), and perhaps this capacity has been impacted to a greater extent by inactivity. 
Importantly, PT2 results were significantly better than those attained on PT1 in three tests (SU, SHR and 1KM). This circumstance suggests that some adaptations did not wholly decay. However, the mechanism whereby participants who resume PA practice after a few weeks of inactivity achieved better performance than participants who have never practiced PA is not clear. Some authors attribute this circumstance to human muscle memory, but this theory has not been confirmed in humans yet (Snijders et al., 2020).

The present study has also verified that two classes of PE per week in college-aged participants allowed them, both in the intervention period 1 and 2, to attain significant improvements in physical fitness with large effect sizes. We understand that these great improvements occurred because the participants were untrained and had a greater adaptative reserve (Aceña et al., 2007). In this regard, some studies carried out with primary and secondary students ascertained that three or more PE classes per week provide the individuals with additional benefits, which includes improved physical fitness and health, value formation and improved academic performance (Kühr et al., 2020). Unfortunately, no studies have examined this circumstance with college students. However, the World Health Organization recommendations on PA for adults aged between 18 to 64 highlight that doubling the recommended practice time (150 minutes of moderate-intensity aerobic PA during the week or 75 minutes of vigorous-intensity aerobic PA throughout the week or an equivalent combination of moderate- and vigorous-intensity activity) generates further health benefits (World Health Organization, 2013). Therefore, future research might examine whether the practice of more than two hours or sessions of PE per week generates additional benefits for college students.

Another aspect that must be taken into account is that participants in the present study were untrained individuals who did not practice either regular or structured PA. Therefore, according to the principle of progression (Roldán, 2009), it cannot be ruled out that if these participants practice PA on a regular basis, in the future, they would need a higher weekly frequency or PA volume to continue improving their physical condition, as occurs in well-trained athletes (Elvar, Donate, Medrano, Costa, \& Soro, 2007).

Finally, it is necessary to mention the limitations of the study. The first one was not having included a control group. This option was not possible because the University curriculum states that all students must actively participate in PE lessons, including injured subjects, which receive curricular adaptations. Likewise, it would have been useful to have carried out, in addition to the field tests, specific laboratory tests, to determine the effects of PE practice, cessation and resumption on health.

\section{CONCLUSION}

Participating in two classes of PE per week for nine weeks improves physical fitness in untrained college students. These improvements almost entirely decay after nine weeks of inactivity, but can be recovered with another nine weeks of PE classes. Individuals who resume their PE classes after nine weeks of PE practice, followed by a nine-week inactivity period, could attain higher improvements in certain physical capacities (muscular endurance, cardiovascular endurance, speed and agility) than those participants who never exercised previously. 


\section{PRACTICAL APPLICATIONS}

Integrating sport into PE curriculum activities at the university level must be considered by PE teachers for the following reasons (Rodríguez, Giménez, Abad, \& Robles, 2015; Malm, Jakobsson, \& Isaksson, 2019): a) Are useful to improve physical fitness; b) Promote value formation; c) Provide the PE curriculum with variety; d) They are useful in establishing lifetime habits of PA practice; and e) Promote socialization.

Moreover, since adaptations attained through the practice of PE are reversible after periods of inactivity, it is necessary to undertake awareness campaigns among college students to promote the continued and regular practice of PA when PE lessons are not provided (final exams and holidays) (Alkhateeb et al., 2019). In the case of Saudi Arabia, it is a pressing need due to the low levels of PA practice (Almutairi et al., 2018).

\section{REFERENCES}

Aceña, R.M., Díaz, G., González, J.M., Juárez, D., \& Navarro, F. (2007). Effect on the strength improvement and retention during a training program with concentrated loads in non-trained subjects. Revista Internacional Ciencias del Deporte, 77(3), 24-33.

Alizadeh, S., Rayner, M., Mahmoud, M., \& Behm, D. G. (2020). Push-ups vs. bench press differences in repetitions and muscle activation between sexes. Journal of Sports Science and Medicine, 19(2), 289-297.

Alkhateeb, S.A., Alkhameesi, N.F., Lamfon, G.N., Khawandanh, S.Z., Kurdi, L.K., Faran, M.Y., et al. (2019). Pattern of physical exercise practice among university students in the Kingdom of Saudi Arabia (before beginning and during college): a cross-sectional study. BMC Public Health, 19, 1716. DOI: 10.1186/s12889-019-8093-2

Almutairi, K.M., Alonazi, W.B., Vinluan, J.M., Almigbal, T.H., Batais, M.A., Alodhayani, A.A., et al. (2018). Health promoting lifestyle of university students in Saudi Arabia: a cross-sectional assessment. BMC Public Health, 18(1), 1093. DOI: 10.1186/s12889-018-5999-z

American Alliance of Health, Physical Education, Recreation, and Dance. (1980). Health-related physical fitness test manual. Reston, VA: American Alliance for Health, Physical Education, Recreation and Dance.

Bakeman, R. (2005). Recommended effect size statistics for repeated measures designs. Behavior Research Methods, 37(3), 379-384.

Blocquiaux, S., Gorski, T., Van Roie, E., Ramaekers, M., Van Thienen, R., Nielens, H., et al. (2020). The effect of resistance training, detraining and retraining on muscle strength and power, myofibre size, satellite cells and myonuclei in older men. Experimental Gerontology, 133, 110860. DOI: 10.1016/j.exger.2020.110860

Borges, A. (2014). Developing agility; its links with the speed and strength; theory and practical experience in working with sprinters. Revista de Entrenamiento Deportivo, 28(2). Retrieved August 12, 2020, from the: https://g-se.com/speed-and-agility-development-and-theory-1682-sa-e57cfb27240714

Bosquet, L., \& Mujika, I. (2012). Detraining. In: I. Mujika (Ed..), Endurance training - Science and practice, $1^{\text {st }}$ Ed., (p.99-106). Vitoria-Gasteiz: Iñigo Mujika.

Calestine, J., Bopp, M., Bopp, C.M., \& Papalia, Z. (2017). College student work habits are related to physical activity and fitness. International Journal of Exercise Science, 10(7), 1009-1017.

Chtourou, H., Ammar, A., Nikolaidis, P., Abdel Karim, O., Souissi, N., Chamari, K., et al. (2015). Postresistance training detraining: Time-of-day effects on training and testing outcomes. Biological Rhythm Research, 46(6), 897-907.

Clemente, F.M., Nikolaidis, P.T., Martins, F.M., \& Mendes, R.S. (2016). Physical activity patterns in university students: Do they follow the public health guidelines? PloS One,11(3), e0152516. DOI: 10.1371/journal.pone.0152516

El Bcheraoui, C., Tuffaha, M., Daoud, F., Kravitz, H., Al Mazroa, M.A., Al Saeedi, M., et al. (2016). On your mark, get set, go: Levels of physical activity in the Kingdom of Saudi Arabia, 2013. Journal of Physical Activity and Health, 13(2), 231-238.

Elvar, J.R., Donate, F.I., Medrano, I.C., Costa, M.R. \& Soro, J.M. (2007). Determination of training load for health-oriented strength improvement (Muscular Fitness). Retrieved August 12, 2020, from the: https://gse.com/determinacion-de-la-carga-de-entrenamiento-para-la-mejora-de-la-fuerza-orientada-a-la-saludfitness-muscular-794-sa-K57cfb27188271 
Fausto-Iván, G.G., \& Aldas-Arcos, H.G. (2019). Physical Education as a complementary subject in engineering careers in Ecuadorian Higher Education. Podium. Revista de Ciencia y Tecnología en la Cultura Física, 14(1), 93-104. Retrieved August 12, 2020, from the World Wide Web: http://podium.upr.edu.cu/ index.php/podium/article/view/784

Fernández-Bustos, J.G., Méndez-Giménez, A., \& Sánchez-Gómez, R. (2018). Teaching physical education at high school based on model-centered instruction. Madrid: Síntesis

Fernández-Santos, J.R., Ruiz, J.R., Cohen, D.D., González-Montesinos, J.L., \& Castro-Piñero, J. (2015). Reliability and validity of tests to assess lower-body muscular power in children. Journal of Strength and Conditioning Research, 29(8), 2277-2285.

García-García, A.M., Ramos-Bermúdez, S., \& Aguirre, O.D. (2016). Scientific quality of field tests to calculate VO2max: Systematic review. Revista Ciencias de la Salud, 14(2), 247-60.

Gavanda, S., Geisler, S., Quitmann, O.J., Bauhaus, H., \& Schiffer, T. (2020). Three weeks of detraining does not decrease muscle thickness, strength or sport performance in adolescent athletes. International Journal of Exercise Science, 13(6), 633-644.

Griban, G., Tymoshenko, O., Arefiev, V., Sushchenko, L., Domina, Z., Malechko, T., et al. (2020). The role of physical education in improving the health status of students of special medical groups. Wiadomosci Lekarskie, 73(3), 534-540.

Hall-López, J.A. (2020). Physical activity levels in physical education teachers before and during school suspension brought by the COVID-19 quarantine. Facta Universitatis Series Physical Education and Sport, 18(2), 475-481.

Harris, J. (2015). Association for Physical Education Health Position Paper. Retrieved August 12, 2020, from the: https://repository.lboro.ac.uk/articles/Association_for_Physical_Education_Health_Position_Paper_2015_19610562

Hashim, A., Ariffin, A., Hashim, A.T., \& Yusof, A.B. (2018). Reliability and validity of the $90^{\circ}$ push-ups test protocol. International Journal of Scientific Research and Management, 6(06), PE-2018. DOI: 10.18535/ijsrm/ v6i6.pe 01

Irwin, J.D. (2004). Prevalence of university students' sufficient physical activity: a systematic review. Perceptual and motor skills, 98(3), 927-943.

Komsis, S., Gissi, M., Papadopoulou, Z., Komsis, G., Dalianas, A. \& Bekris, E. (2018). Detraining effects of the transition period on endurance and speed -related performance parameters of amateur soccer players. International Journal of Scientific Research, 7(2), 40-42.

Kühr, P., Lima, R.A., Grøntved, A., Wedderkopp, N., \& Klakk, H. (2020). Three times as much physical education reduced the risk of children being overweight or obese after 5 years. Acta Paediatrica, 109(3), 595-601.

Lipert, A., Matusiak-Wieczorek, E., Kochan, E., Szymczyk, P., Wrzesińska, M., \& Jegier, A. (2020). Physical activity of future health care professionals: adherence to current recommendations. Medycyna Pracy, 71(5), 1-11.

Malm, C., Jakobsson, J. \& Isaksson, A. (2019). Physical activity and sports-real health benefits: a review with insight into the public health of Sweden. Sports (Basel, Switzerland), 7(5), 127. DOI: 10.3390/sports7050127

Mandić, D., Bjegović-Mikanović, V., Vuković, D., Đikanović, B., Stamenković, Z., \& Lalić, N. M. (2020). Successful promotion of physical activity among students of medicine through motivational interview and Web-based intervention. PeerJ, 8, e9495. DOI: 10.7717/peerj.9495

Meckel, Y., Galily, Y., Nemet, D., \& Eliakim, A. (2011). Changes in weight indexes and aerobic fitness of physical education students over three years of college. Journal of Human Sport and Exercise, 6(1), 112-121.

Oliveira, A., Monteiro, Â., Jácome, C., Afreixo, V., \& Marques, A. (2017). Effects of group sports on healthrelated physical fitness of overweight youth: A systematic review and meta-analysis. Scandinavian Journal of Medicine and Science in Sports, 27(6), 604-611.

Psilander, N., Eftest $\varnothing 1$, E., Cumming, K.T., Juvkam, I., Ekblom, M.M., Sunding, K., et al. (2019). Effects of training, detraining, and retraining on strength, hypertrophy, and myonuclear number in human skeletal muscle. Journal of Applied Physiology, 126(6), 1636-1645.

Ramírez-Vélez, R., Rodrigues-Bezerra, D., Correa-Bautista, J.E., Izquierdo, M., \& Lobelo, F. (2015). Reliability of health-related physical fitness tests among colombian children and adolescents: The FUPRECOL study. PloS one, 10(10), e0140875. DOI: 10.1371/journal.pone.0140875

Ramos, J. (2000). Strategies to increase motor skills practice time in Physical Education classes. Apunts, 59, 22-30.

Reid, C., Dolan, M. \& Debeliso, M. (2017). The reliability of the standing long jump in NCAA track and field athletes. International Journal of Sports Science, 7(6), 233-238.

Rodríguez, J., Giménez, F.J., Abad, M.T., \& Robles, A. (2015). El desarrollo curricular del deporte según la percepción del profesorado desde una perspectiva cualitativa (Curriculum development in sport according to teachers' perceptions from a qualitative perspective). Retos, 27, 98-104. In Espagnol

Roldán, E.E. (2009). Physiological bases of the of sport training principles. Revista Politécnica, 5(8), 84-93.

Ronconia, M., \& Alvero-Cruza, J.R. (2008). Physiological changes resulting from detraining. Apunts, 43(160), $192-198$ 
Ruiz, J.R., España Romero, V., Castro Piñero, J., Artero, E.G., Ortega, F.B., Cuenca García, M., et al. (2011). ALPHA-fitness test battery: Health-related field-based fitness tests assessment in children and adolescents. Nutrition Hospitalaria, 26(6), 1210-1214.

Snijders, T., Aussieker, T., Holwerda, A., Parise, G., van Loon, L., \& Verdijk, L. B. (2020). The concept of skeletal muscle memory: Evidence from animal and human studies. Acta Physiologica (Oxford, England), 229(3), e13465. DOI: 10.1111/apha.13465

Tran, T., Lundgren, L., Secomb, J., Farley, O., Haff, G., Nimphius, S., et al. (2017). Effect of four weeks detraining on strength, power, and sensorimotor ability of adolescent surfers. The Open Sports Sciences Journal, 10(1), 71-80.

Tsolakis, C.K., Vagenas, G.K., \& Dessypris, A.G. (2004). Strength adaptations and hormonal responses to resistance training and detraining in preadolescent males. Journal of Strength and Conditioning Research, $18(3), 625-629$.

Waldhelm, A., \& Li, L. (2012). Endurance tests are the most reliable core stability related measurements. Journal of Sport and Health Science, 1(2), 121-128.

Wang, J. (2019). The association between physical fitness and physical activity among Chinese college students. Journal of American College Health, 67(6), 602-609.

World Health Organization (2013). Global Recommendations on Physical Activity for Health. Retrieved November 1, 2020, from the World Wide Web: https://www.who.int/dietphysicalactivity/factsheet_recommendations/en/

Zamarripa-Rivera, J.I., Ruiz-Juan, F., López-Walle, J.M.A., \& Fernández, R. (2014). Frequency, duration, intensity and physical activity levels during leisure time in adult people in Monterrey (Nuevo León, México). Espiral. Cuadernos del Profesorado, 7(14), 3-12.

\section{FIZIČKO VASPITANJE: VEŽBANJE, PRESTANAK I NASTAVAK NEUTRENIRANIH SAUDIJSKIH STUDENATA}

Cilj ove studije bio je dvojak: prvo, da se proveri da li su dva časa nedeljno fizičkog vaspitanja (FV) dovoljna za poboljšanje fizičke spremnosti studenata. Drugo, da se utvrdi efekat vežbanja, prestanka i nastavka vežbanja u okviru FV na navedene studente. Trideset (30) neutreniranih saudijskih studenata pohađalo je časove PE dva puta nedeljno tokom devet nedelja. Nakon toga, bili su neaktivni devet nedelja, i konačno, ponovo su pohađali časove PE tokom još jednog perioda od devet nedelja. Posle dva devetonedeljna perioda FV, ispitanici su poboljšali snagu, izdržljivost, brzinu i agilnost. Period neaktivnosti podrazumevao je gubitak svih adaptacija postignutih tokom prvih devet nedelja vežbanja, osim mišićne izdržljivosti mišića fleksora trupa. Dva časa nedeljnog FV tokom devet nedelja poboljšavaju fizičku spremnost neutreniranih studenata univerziteta. Ova poboljšanja gotovo u potpunosti nestaju nakon devet nedelja neaktivnosti, ali se mogu dostići sa još devet nedelja časa FV. Pojedinci koji nastave časove FV nakon devet nedelja fizičkog vaspitanja, nakon čega sledi devetonedeljni period neaktivnosti, mogli bi da ostvare veća poboljšanja u određenim fizičkim kapacitetima (mišićna izdržljivost, kardiovaskularna izdržljivost, brzina i agilnost).

Ključne reči: fizičko vaspitanje, kontinuitet, učestalost, reverzibilnost 